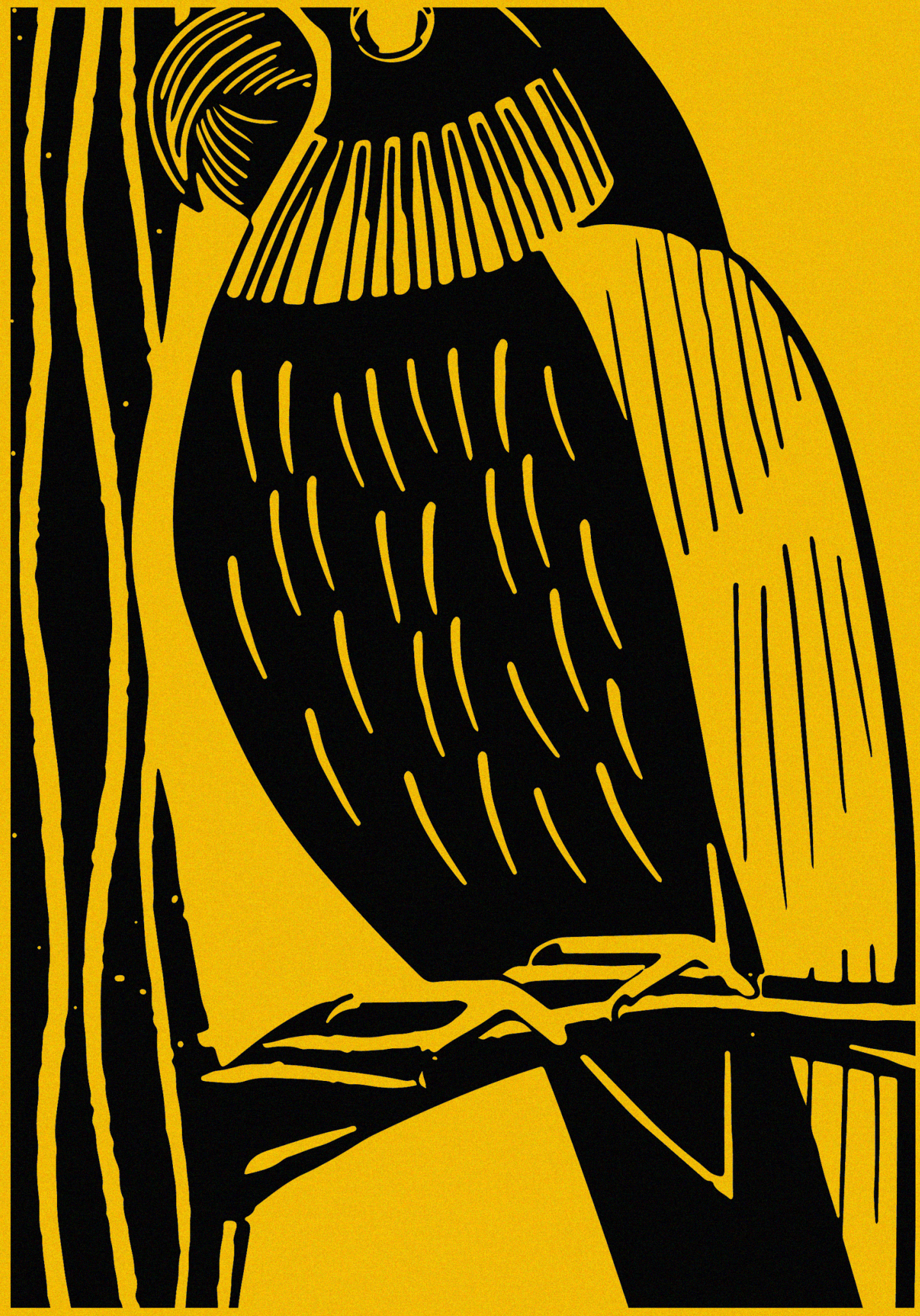




\section{Homenagem a Paulo Freire aprendi lendo Caju ${ }^{1}$}

Para a Pró-reitora de Extensão Claudia Mayorga, pelo estímulo e o afeto, de quem acredita na força expressiva da arte popular no processo educacional. E aos meus colegas de luta do Teatro Universitário, em parceria com o Programa Polos de Extensão Pesquisa e Ensino da Fac. de Direito da UFMG, que, como o Mestre Paulo Freire, lutam para dar voz a quem não tem.

\section{Prof. Fernando Limoeiro, ora conhecido como o cordelista: Vitorino- Sabe-ler.}

Meus amigos camaradas

Prestem muita atenção!

A história que eu vou contar

Pertence a toda nação

É a história de um cego

Que serve bem de lição:

O meu nome é Vitorino

Que herdei do meu avô

Junto com a fama dura

De ser bom atirador

Melhor ainda na enxada

Seja na chuva, ou calor

Nasci em Xorropotó

Agreste do meu sertão

No meu sítio só tem água

Quando o rio dá vazão

Ou quando a chuva premia

Com as gotas da emoção
A miséria é muito ruim

E tem em qualquer lugar

Mas a pobreza sem água

Acredite: É de lascar!

Ver a criação morrer

Sem ter como ajudar

Mas também há outra sede

Que faz a gente tremer

Vem misturada com a fome

Da cultura e do saber

Que eu só vim descobrir

Depois que aprendi a ler

Depois de muito vexame

Que cego não percebia

Depois de engolir mentiras

Que meu patrão me emitia

De ser passado pra trás

Seja de noite ou de dia

\footnotetext{
${ }^{1}$ Um resumo do cordel ora publicado foi interpretado pelo prof. Fernando Limoeiro na $20^{\mathrm{a}}$ Jornada de Extensão da UFMG, realizada em 16 de junho de 2021. O video da apresentação encontra-se disponivel em: https://www.youtube. com/watch?v=BSW1YZSDmvk. Acesso em: 28 jun. 2021.
} 
Um auxílio do governo

Nós passamos a receber

Mas tinha cheiro de esmola

Para quem não sabe ler

Principalmente meu avô

Que precisava escrever

E morria de vergonha

Pra assinar o documento

Dizia que era uma mistura

De lavrador com jumento

Pra quem não ler e não escreve

Receber é um sofrimento

Eu respeitava meu avô

E sentia seu tormento

O sujeito que não ler

Sente vergonha por dentro

É um cego tendo olho

Sente muito acanhamento

Mas o pior era eu

Que era um jumento novo

Um respeitado vaqueiro

Que todo mundo temia

Fingindo que era sabido

Mas que de nada sabia

Meu avô adoeceu

E eu passei a receber

Ocupando seu lugar

Mesmo sem saber ler

Sem nunca contar a ele

Que nunca soube escrever
Um dia eu estava no banco

Pra receber com acanhamento

Quando a mocinha do caixa

Percebeu meu sofrimento

- Moço, não há razão

Pra esse envergonhamento

- Todo trabalhador

Merece grande respeito

Se o senhor não sabe ler

Inda é tempo e tem direito

De aprender ler e escrever

Tornar-se um livre sujeito!

Fomos para uma palestra

De um professor arretado

Chamado de Paulo Freire

Um mestre muito afamado

Cada coisa que dizia

Me deixava entusiasmado

Mas quero lhe confessar

Fui tremendo e acanhado

Mas as palavras que ouvia

Me deixava iluminado

Como se um novo mundo

Tivesse descortinado

O mestre falava simples

E todo mundo entendia

Que ler também abre o pensar

Era o que ele mais queria

Que você lesse a palavra

E o que ela pretendia 
Todo lavrador bem sabe

Além de plantar, pensar

E desvendando as palavras

Bem melhor raciocinar

E já sabendo escrever

Seus desejos registrar

O senhor pode acreditar

Que eu fiquei arrepiado

E ainda escondi na hora

Os meus olhos marejados

Confesso, desde esse dia

Que eu me senti transformado

Entrei num curso noturno

Que só tinha lavrador

Ganhei livros e cadernos

Parecia um professor

Em poucos dias, acredite

O saber me dominou

Eu perdi toda vergonha

De repetir, perguntar

E a fome foi aumentando

De ler e de "escrevinhar"

Além de aprender também

Diminuir e somar

Como fez o mestre Freire

Pra acabar a ignorância

Somou seu grande saber

Com amor e tolerância

Iluminando a consciência

Na velhice ou na infância
E disse pra minha mestra

E para a classe escutar:

- Escutei a vida inteira

Com medo de duvidar:

- "Que um papagaio velho

Jamais aprende a falar"

Mas o mestre Paulo Freire

Mudou logo meu pensar

- "Que o homem sem leitura

É fácil de dominar

Cai em qualquer armadilha

Que o poderoso aplicar"

A senhora aprendeu bem

Como o mestre a ensinar

A ler palavras da vida

Que a gente sabia usar

Roçado, enxada, partilha

Logo aprendi soletrar

Juntei um "cê" com um "a"

E um "jota" com um "u"

E pude escrever sozinho

A doçura do caju

Que plantei quando menino

Com sol quente e céu azul!

E tudo que eu julgava

Que era dificil de ler

Com as palavras do trabalho

Logo aprendi a escrever

Fui tomando consciência

E querendo mais saber 
Eu juro professorinha

Que deve se orgulhar

De cada turma de cego

Que ajudou a enxergar

E ninguém nos fazer de bobo

E nosso destino domar.

Foi na luz do candeeiro

Que Eu treinei sem parar

Escrevia e repetia

As letras do bê a bá

E com elas fui juntando

Para palavras formar

Caju, feijão, macaxeira

Milho verde pra assar

Escrevi pé de umbu

Galinha, guiné, preá

Mangaba doce e sapoti

Umbu e também cajá

A professora aos poucos

Sentia admiração

E me deu outro caderno

Para eu treinar a lição

Logo misturei o juizo

Com as coisas do coração.

Mas confesso que a mestra

Só demonstrou vaidade

Quando me viu escrevendo

A palavra liberdade

Ela viu que estava certa

Eu escrevi felicidade!
Um dia fiz a besteira

De mostrar para o patrão

Que eu já sabia escrever

E ler sem erro a lição

Esperando o elogio

E a sua admiração

- Seu lugar é no roçado

Cuidando da plantação

Que é disso que depende

O lucro do seu patrão

Leitura não rende nada

E ainda dá confusão

- Fica metido a besta

Lendo jornal e revista

E quando menos se espera

Tem ideia de comunista

Tua caneta é a enxada

Que é o orgulho do nortista

- Isso é o que o senhor pensa

Mas aprendi diferente

A escola toda noite

Me faz mais inteligente

Até a lua se orgulha

Em me ver mais consciente

Um dia eu estava no banco

Pra receber com acanhamento

Quando a mocinha do caixa

Percebeu meu sofrimento

- Moço, não há razão

Pra esse envergonhamento 
Saí de cabeça erguida

Sou lavrador do saber

Que em breve vai plantar

Outra forma de viver

Ensinando a meus irmãos

O valor de aprender

Eu costumei ter que ir

Ao banco pra receber

Levei uns belos cajus

Pra mocinha agradecer

E ela ficou espantada

Porque eu sabia escrever

Me disse emocionada

Pelos conselhos que deu

E ainda pelo cartão

Que eu escrevi e ela leu

Estava ali novo homem

Como um presente de Deus

"Tem muita gente sedenta

Doidinha pra aprender ler

E junto com as palavras

Pensar bem e debater

Fugir da dominação

Usando bem o saber."

"Todo homem tem direito

De mostrar o seu pensar

E defender o que é seu

Quando ele discordar

Lutar pelos seus direitos

Ler tudo o que assinar"
E no fim do outro mês

Quando vim pra receber

No caminho para o banco

Tudo eu gostava de ler

Lia letreiro de ônibus

Muito lugar pra comer

Já trouxe outro cartão

Que com alegria ela leu:

Quem luta e se alfabetiza

Torna o mundo mais seu

Já não é mais dominado

Descobre o que padeceu

Minha doce professora

Com Paulo Freire aprendeu

E com o saber dos alunos

Misturou e engrandeceu

Quem ensina sempre aprende

Com minha turma ela aprendeu

Trocou mil conhecimentos

Viu nossa realidade

Ensinou com essa mistura

E aprendemos de verdade

A dizer o que sentimos

E lutar pela igualdade

Foi aí que ela me disse

Você já está preparado

Para ouvir essa notícia

Que nos deixa revoltado:

Paulo Freire foi expulso

Por nos ter conscientizado! 
E o que é mais perigoso

Por nos ter politizado

Fazer do aluno que ler

É um cabra bem informado

E que depois da leitura

Nunca mais é dominado!

Expulso do seu torrão

Para não ser torturado

Por espalhar o saber

E o pensamento apurado

Como aprender ilumina

Deixa mais capacitado.

De fato eu fiquei zangado

Como é triste a ingratidão!

Um governo que faz isso

Não merece meu perdão

E nem tão pouco o respeito

De um eleitor cidadão.

Comecei a ler os livros

Que ela me ofereceu

Livros de Paulo Freire

Deve ler, quem já não leu

Educação como prática

E mais livros me ofereceu

Do valor da liberdade

Pedagogia do Oprimido

Que eu confesso que foi esse

O que mais mexeu comigo

Ganhei de Cláudia Mayorga

Me senti muito querido
Vendi minha parte no sítio

Que meu pai tinha comprado

E o patrão bancava o dono

Do que se tinha plantado

Fui embora pra cidade:

Só volto quando formado!

Fui ser vigia num banco

Meu dinheiro foi poupado

De noite fiz um cursinho

De manhã andava armado

E tive a sorte danada

De nunca ser assaltado

Eu varava madrugadas

Mudando de apostila

Dormia em cima dos livros

Usava grande mochila

De manhã ainda estudava

Com a mente bem tranquila

Meu remédio era lembrar

Do mestre a grande lição

Que o pobre que estuda

É guerreiro e cidadão

E por ser trabalhador

Merece até louvação!

Cada ano que passava

Sentia perto a vitória

Como um grande corredor

Conquistando sua glória

E a Taça Paulo Freire

Premiando minha história 
Até que chegou a hora

Da bendita formatura

A moça do banco foi

O presente era uma mistura

De caju com meu diploma

Mais o canudo da luta

Sou um bom advogado

Passei em terceiro lugar

Comprei o sítio sonhado

Que pai queria comprar

E o patrão endividado

Nem queria acreditar

E assim meus camaradas

Terminou meu desatino

Acabou minha cegueira

No livro do meu destino

Posso o cordel assinar

Como Dr. VITORINO!

BH, 12 de Junho de 2021 